\title{
COMUNICACÕES
}

\section{Rhizoctonia solani AG1-IA causing leaf blight in Erythrina indica var. picta in Brazil}

\author{
Alessandra de Jesus Boari ${ }^{1}$, Ayane Fernanda Ferreira Quadros ${ }^{2}$, Kátia de Lima Nechet ${ }^{3}$
}

\begin{abstract}
${ }^{1}$ Embrapa Amazônia Oriental, 66095-100, Belém, PA, Brazil; ${ }^{2}$ Universidade Federal Rural da Amazônia, 66077-830, Belém, PA, Brazil; ${ }^{3}$ Embrapa Meio Ambiente, 13820-000, Jaguariúna, SP, Brazil.

Autor para correspondência. Kátia de Lima Nechet(katia.nechet@embrapa.br)

Data de chegada: 28/06/2017. Aceito para publicação em: 18/08/2017.
\end{abstract}

$10.1590 / 0100-5405 / 181932$

Erythrina indica var. picta (L.) B. \& M. (Fabaceae), commonly known as brasileirinho, sunshine tree or coral tree, is a rustic ornamental tree widely used in gardens in Brazil. In March of 2014, leaf blight and intense defoliation in E. indica var. picta were observed in Moju, PA, Brazil (Fig. 1A). The spots were characterized by the presence of mycelia on the leaf surface (Fig. 1A). Microscopic examination of the mycelia revealed association with Rhizoctonia spp. The characteristics observed were a distinct right-angle branching pattern, the constriction of hyphae near the point of origin, and multinucleate individual hyphae compartments (1). The fungus was isolated from infected tissues on potato-dextrose-agar (PDA). The anastomosis group (AG) was determined by pairing the isolate with the following tester strains of multinucleate Rhizoctonia solani group: AG1- IA (CMAA 908) AG1-IB (CMAA 909); AG-2-2 IIIB (CMAA 907); AG3 (CMAA 906); AG4 AHI (CMAA 903); AG4 140 (CMAA 904); AG7-H0 (CMAA 901); AG-BI TS-2-4 (CMAA 905) (2). The isolates were obtained from the Culture Collection of Microorganisms of Environmental and Agricultural Importance (CMAA) of the Brazilian Agricultural Research Corporation, located in Jaguariúna, São Paulo. The isolate of E. indica var. picta anastomosed with AG1-IA. The genomic DNA of the isolate was extracted (3), and the ITS-5.8S region was amplified by using the pair of primers ITS4B/ ITS1F. The amplicons were cloned by using pGEM-T Easy Vector Sys-
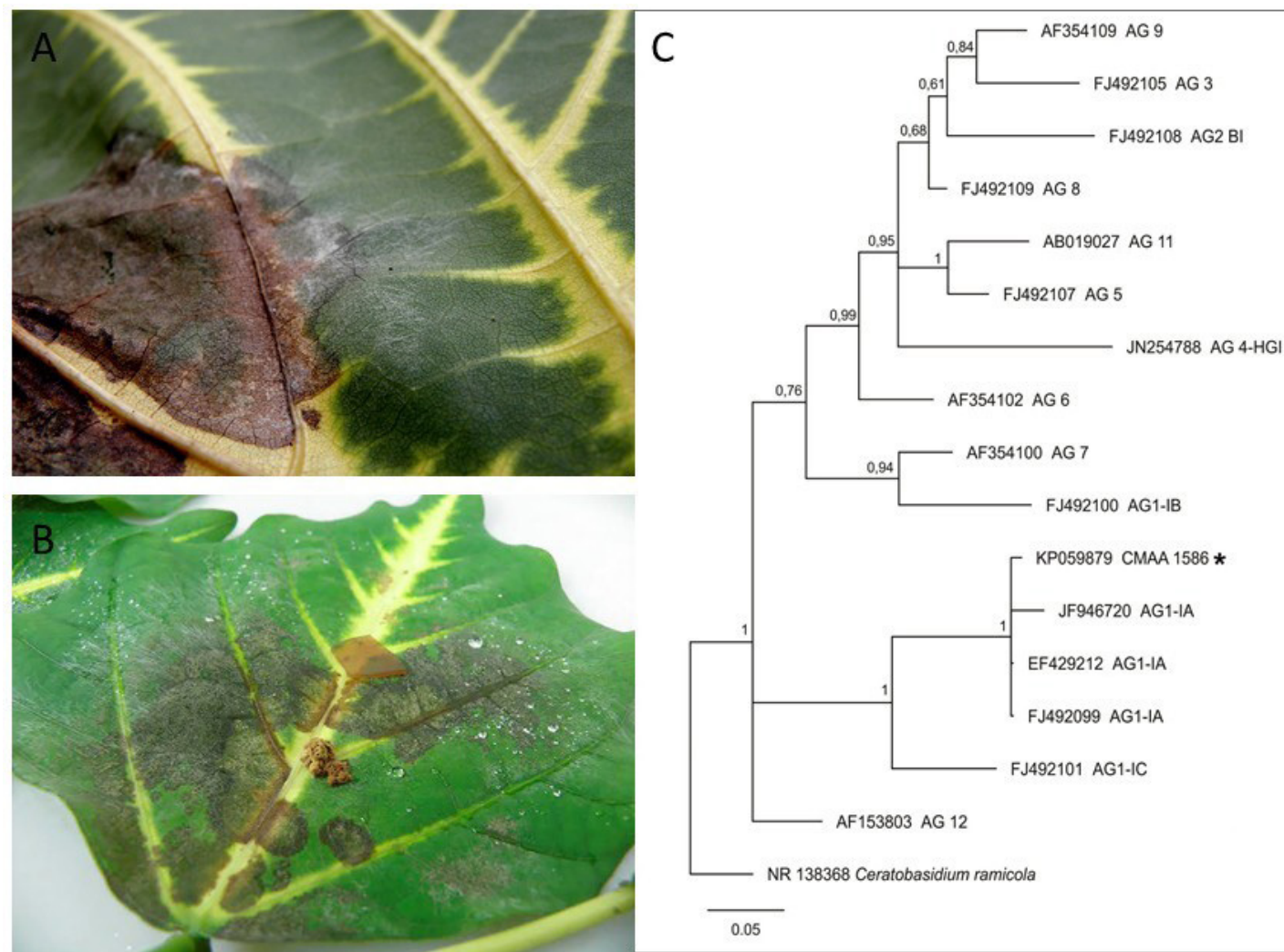

Fig. 1 A. Symptom of leaf blight in Erythrina indica var. picta in the field caused by Rhizoctonia solani AG1-IA; B. Leaf blight on E. indica var. picta five days after inoculation with $R$. solani AG1-IA; C. Phylogenetic tree of isolates from different anastomosis group of Rhizoctonia solani obtained from GenBank by Bayesian inference based on the ITS sequence. The isolate of $E$. indica var. picta CMAA 1586 (KP059879) is marked with an asterisk. Node labels indicate posterior support probability. The sequence of Ceratobasidium ramicola was employed as an outgroup. 
tem (Promega) kit and the competent Escherichia coli cells OneShot ${ }^{\mathbb{B}}$ DH5 $\mathrm{a}^{\mathrm{TM}}$ (Invitrogen, San Diego), which were then used in the PCR reaction. The sequencing reactions were done in Applied Biosystems ${ }^{\circledR}$ 3500 Genetic Analyzer. The pathogenicity test was performed by inoculating healthy leaves with mycelium discs of the isolate. The control leaves were inoculated with PDA discs. After inoculation, the leaves were covered with plastic bags for $24 \mathrm{~h}$ and maintained at $28^{\circ} \mathrm{C}$. After five days, foliar necrosis was observed only on inoculated leaves (Fig. 1B). The fungus was reisolated fulfilling Koch's postulates. The isolate sequence (715 bp) was deposited in the GenBank (access: KP059879) with $99 \%$ identity with $R$. solani accesses from beet (FJ492099) and rice (EF429212) AG1-IA. In the phylogenetic tree of the ITS-5.8S region, the isolate was clustered with $R$. solani isolates belonging to AG1-IA (Bayesian posterior probability $=1)($ Fig. 1C). The isolate was deposited in CMAA (access code CMAA 1586). The results of this study confirmed the fungus $R$. solani AG1-IA as the etiological agent of E. indica var. picta leaf blight in Brazil. In the Amazon region, the occurrence of $R$. solani AG1-IA has been reported in important cultures, such as soybean (4), rice (5), and cowpea (6). The current studies of genetic population of $R$. solani AG1 IA suggest its potential to emerge as a pathogen in new hosts based on the mixed reproductive system of the pathogen, including both sexual reproduction and long-distance dispersal of adapted clones, its genetic diversity and population size (7). These characteristics can support the origin of the emergence of R. solani AG1 IA in Erythrina indica var. picta.

\section{ACKNOWLEDGMENTS}

The authors are grateful for the financial support provided by FINEP.

\section{REFERENCES}

1. Sneh, B.; Burpee, L.; Ogoshi, A. Identification of Rhizoctonia Species. St. Paul, APS Press, 1994. 133p.

2. Ceresini, P.C.; Fenille, R.C.; Souza, N.L. Associação de Rhizoctonia spp. binucleadas e de $R$. solani Kühn GA 4 HGI a vagens de amendoinzeiro (Arachis hypogaea) no estado de São Paulo. Summa Phytopathology, v.22, n. p.145-156,1996.

3. Gibbs, A.; Mackenzie, A. A primer pair for amplifying part of the genome of all potyvirids by RT-PCR. Journal of Virology Methods, Hong Kong, v.63, p.9-16, 1997.

4. Youssef, D.R.; Souza, G.R.; Nechet, K.L.; Halfeld-Vieira, B.A. Caracterização de isolados de Rhizoctonia associados à queima foliar em Roraima. Revista Agro@mbiente On-line, Boa Vista, v.6, p.158-165, 2012.

5. Sousa, E.C.; Kuramae, E.E.; Nakatani, A.K.; Basseto, M.A.; Prabhu, A.S.; Ceresini, P.C. Caracterização citomorfológica, cultural, molecular e patogênica de Rhizoctonia solani Kühn associado ao arroz em Tocantins, Brasil. Summa Phytopahologica, v. 33, p.129-133, 2007.

6. Nechet, K.L.; Halfeld-Vieira, B.A. Caracterização de isolados de Rhizoctonia spp., associados à mela do caupi (Vigna unguiculata), coletados em Roraima. Fitopatologia Brasileira, Brasília, v. 31, p. $505-508,2006$

7. Chavarro Mesa, E.; Ceresini, P. C.; Ramos Molina, L. M.; Pereira, D. A. S.; Schurt, D. A.; Vieira, J. R.; Poloni, N. M.; Mcdonald, B. A. The Urochloa foliar blight and collar rot pathogen Rhizoctonia solani AG-1 IA emerged in South America via a host shift from rice. Phytopathology, St. Paul, v. 105, p. 1475-1486, 2015. 